\title{
IRISH STUDIES ROUND THE WORLD - 2018
}

Christina Hunt Mahony (ed.)

Copyright (c) 2019 by the authors. This text may be archived and redistributed both in electronic form and in hard copy, provided that the author and journal are properly cited and no fee is charged for access.

\section{Introduction}

Christina Hunt Mahony .254

New Crops, Old Fields: Reimagining Irish Folklore.

Eamon Byers and Conor Caldwell, eds.

Eduardo Barros-Grela .256

Flann O'Brien: Problems with Authority.

Ruben Borg, Paul Fagan and John McCourt, eds.

Germán Asensio Peral

Kate O'Brien and Spanish Literary Culture.

Jane Davison.

Verónica Membrive Pérez...

.263

Stinging Fly Stories.

Sarah Gilmartin and Declan Meade, eds.

Ángela Rivera Izquierdo.

\section{Bloodroot.}

Annemarie Ní Churreáin.

Manuela Palacios González

Conversations with Friends.

Sally Rooney.

José Francisco Fernández 
Last Stories.

William Trevor.

Hedwig Schwall

273

\section{Rhythms of Writing: An Anthropology of Irish Literature.}

Helena Wulff.

Christina Hunt Mahony 276

Introduction

\section{Christina Hunt Mahony}

As I write, Ireland's decade of centenaries continues with eyes focused on the forthcoming First World War armistice centennial observance, along with that of the crucial 1918 Dail Election, the first election in which (some) women were enfranchised, and which ushered in an era of more radicalized politics in the country. President Michael D. Higgins, re-elected by a sizable majority in October will be sworn into office once again just hours after the solemn commemorative moment of the $11^{\text {th }}$ hour of the $11^{\text {th }}$ day of the $11^{\text {th }}$ month. Because of its unique overlapping revolutionary history with WWI Ireland has been late in acknowledging their countrymen who fought and died in that war - thus this date is of even greater significance now.

Earlier in the year, though, the centre of attention was rightly focused on the centenary of female suffrage with events taking place over the course of several months throughout the country. In a period when the Me Too Movement, Take Back the Night and reparations related to various Mother and Baby homes have dominated the media, this confluence of foci is both apt in both an historical and a current context. Of course nothing which occurred in the historical or artistic sphere of women's lives this past year in Ireland could compare in significance to the successful Repeal the Eighth referendum, which in turn gave rise to many artistic interpretations and publications, perhaps chief among them Una Mullally's Repeal the Eighth, an anthology of women's writings on reproductive rights.

Major exhibitions opened this year, perhaps foremost among them Listen Now Again the Seamus Heaney exhibit housed at present in The Bank of Ireland Cultural and Heritage Centre in College Green but moving in 2021 to a permanent home in The National Library. Attendance at this brilliantly curated display of artefacts from Heaney's life and work is essential for all Irish Studies professionals. Geraldine Higgins, of Emory University, working closely with the Heaney family, has mounted a visual and aural experience in which the poet's wit, charm, warmth, skill, dedication and genius are adroitly balanced to provide an insight into both the man and his art.

Another evocative and poignant exhibit which was housed first in The Coach House in Dublin Castle but then moved to a most appropriate site in Skibbereen, County Cork, and will in turn travel again in the new year to Derry. Coming Home: Art and the Great Hunger which displayed paintings from Quinnipiac University's Great Hunger Museum in Connecticut, was accompanied by a catalogue issued by Cork University Press containing essays by scholars Niamh O’Sullivan (who curated the exhibit), Laurence Geary and Breandán Mac Suibhne. 
At the National Gallery a long running show of much-loved Irish artist Roderic O'Conor's work shed new light on his development by placing him in a modernist context and hanging his work in relation to French and other Modernist painters by whom he was influenced and with whom he shared ideas.

A unique historical exhibit that is not a replica, but a painstaking restoration, is found now at 10 Henrietta Street - the new tenement museum opened in Dublin's North inner city. The magnificent $18^{\text {th }}$ century townhouse has not been restored to its former aristocratic glory (as have several houses on the street in both public and private hands) but to the state to which it had devolved when as many as a hundred people in dozens of families crowded into its faded splendour. The opening ceremonies included among the invitees people who had been born into great poverty in the house in the early decades of the $10^{\text {th }}$ century.

Ireland, as we know, abounds in cultural events, festivals and summer schools, and I will attempt to give here a description of only a handful. There seem to be more and more each year. One such which deserves to be better known abroad is Dublin's Festival of History which recently celebrated its $6^{\text {th }}$ year and uses the excellent network and facilities of Dublin's libraries to host exhibitions, conferences and lectures by academics, local historians and experts in a variety of fields. This year's focus was on suffragist history.

The much better-known Dublin theatre Festival featured Irish actress Ruth Negga in the title role in Hamlet at the Gate Theatre which played to sold-out houses: Arthur Riordan's upbeat and youthful dramatic reworking of Joyce's Portrait of the Artist, Rough Magic's festival offering at the Abbey along with Druid's Richard III, part of the Galway's theatre company's ongoing Shakespeare project.

Ireland can also now boast a burgeoning opera scene - apart from the well-established Wexford Opera Festival in October, which showcases either minor works of major composers who rarely get an outing, or the work of overlooked composers not usually included in the modern canon. Now, after the merging of Wide Open Opera and Opera Theatre Company the Irish National Opera has entered the scene with offerings such as Bartok's Bluebeard's Castle, one of the highlights of the Theatre Festival; and, earlier in the year, Opera Collective mounted a stunning production of Monteverdi's The Return of Ulysses, directed by former Abbey Theatre Artistic Director, Patrick Mason.

In film news - Lance Daly's Black 47 was a highlight of the Dublin International Film Festival and Thaddeus O'Sullivan's Citizen Lane was shown both in theatres and on RTE. The former is the tale of a British army deserter who returns to his Connemara home during the famine to find his family has been evicted, told in the style of a western. The latter is a multi-approach film which uses fictionalized characters, newsreels and photographs and expert commentary by historians and art historians to tell the whole story of High Lane's doomed attempts to establish a gallery in Dublin and to donate his collection to the city. Tom Vaughan-Lawlor excels as Lane, in a portrayal that incorporates both Lane's most vulnerable and least attractive qualities.

The biggest news in Ireland in books this season must be newcomer Sally Rooney whose second novel, Normal People, was nominated for the Man Booker Prize before its publication date, on the combined strength of advance copies and her earlier work, Conversations with Friends. The recent Trinity College graduate didn't win the Booker, but her future as a writer is surely secured. It was another Irish writer, Ann Burns, a more seasoned writer from Belfast, who was the surprise winner of this year's Booker, for her linguistically innovative novel, Milkman. And, finally, perhaps the most heartwarming news from the world of literary prizes was that of another recent Trinity graduate, Catriona Lally, who was awarded this year's Rooney Prize for her novel, Eggshells. Lally has kept herself going as a writer by working the early morning shifts as a cleaner in Trinity so that she could write later in the day while her daughter is in the crèche in college. Brava Catriona! 
Christina Hunt Mahony directed the postgraduate Center for Irish Studies at The Catholic University of America in Washington, D.C. She is the author of Contemporary Irish Literature: Transforming Tradition and editor of Out of History: Essays on the Writings of Sebastian Barry. She has recently contributed chapters to The Oxford Handbook of Modern Irish Theatre and The Cambridge History of Irish Autobiography and is a Senior Research Fellow in The School of English at Trinity College, Dublin.

cmahony@tcd.ie

New Crops, Old Fields: Reimagining Irish Folklore.

Edited by Eamon Byers and Conor Caldwell.

Bern, Switzerland: Peter Lang, 2017. 180 pp.

ISBN: 978-3-0343-1912-6

\section{Reviewer: Eduardo Barros-Grela (Universidade da Coruña, Spain)}

Traditionally, Irish cultural research has disclosed a rising interest in the discussion of folklore as a cultural artifact in the production of contemporary identities. In particular, scholarly research has focused on the controversial topic of the production of national identifications, which might be considered as marginal in other geographical European environments, but is central to the liminal position of Ireland within Postcolonial Studies. Certain studies are pivotal in the articulation of theory and non-fiction film, and noteworthy examples of such studies could be Eoin Flannery's works on Irish cultural studies or Declan Kiberd's study on subjectivity and postcolonial writing.

New Crops, Old Fields: Reimagining Irish Folklore embarks on the discussion of how tradition works and how it is represented in literature, film, and the arts. The authors introduce the concept of construction as a metaphor to articulate folklore, in the terms of a contemporary recycling of original cultural discourses. By examining this concept, authors Byers and Caldwell do not dodge the problematic definition of tradition, but rather embrace its contradictions and celebrate the controversial nature of the term-not only semantically but ideologically too. They refer to the importance of tackling this notion from diverse approaches that study the relevance of tradition in the construction of a national identity, as cultural nationalists began doing in the nineteenth century, when they "succeeded in researching, recording, reviving and, yes, inventing, folkloric traditions" (2). The provocative position adopted by the authors in their introduction to the book unambiguously draws from Homi Bhabha's notorious opening of Nation and Narration:

Nations, like narratives, lose their origins in the myths of time and only fully realize their horizons in the mind's eye. Such an image of the nation - or narration - might seem impossibly romantic and excessively metaphorical, but it is from those traditions of political thought and literary language that the nation emerges as a powerful historical idea in the west. ... This is not to deny the attempt by nationalist discourses persistently to produce the idea of the nation as a continuous narrative of national progress, the narcissism of self-generation, the primeval present of the Volk. (1) 
Reimagining Irish Folklore adheres to this controversial dichotomy in the production of popular culture as an identity marker, and encompasses a variety of contributions that support this critical premise by offering diverse approaches to the study of the folklore.

The first chapter Diarmuid Ó Giolláin's "Folklore: A Zombie Category", delves into the editor's preoccupations about the semantics of "folklore," and projects the discussion into the current alignment of academic studies with anthropocentric reterritorializations of the discipline. The endurance of folklore as an independent field of study underpins, therefore, Ó Giolláin's reclamation of historical discourses to shelter the autonomy of folkloristics. Thus, the historical deconstruction of the concept reveals, according to the author, its current cultural connotations, which are often associated, in the Irish context, with national sensibilities. He argues that "[w]hile folklore could be interpreted as transmitting a national tradition, it was inherently fragile" (15). Giolláin articulates this idea with his discussion of the ontological plausibility of the "popular", which he situates in the performative component of cultural production, a position that had already been supported by Ulrich Beck in 2002 and García Canclini ten years earlier. The question of cultural authenticity also hovers around Giolláin's well-documented research, and following Steven Feld he alludes to the resignification of the concept as a distinctive quality that can be found in the twenty-first century emergence of explicit hybrid cultural identifications. All in all, this chapter works adequately as the opening contribution to the book, because it offers a social, historical, and academic contextualization of the term "folklore", thus facilitating the readers' engagement with the chapters that follow.

One of the contributions that benefits from Giolláin's theoretical introduction is Manuel Cadeddu's 'Legends and Oral History in Bram Stoker's The Snake's Pass. In his analysis, the author leans on Benedict Anderson's claim that nationalism and nationality are "cultural artefacts" (4) to observe the creation of an Irish identity as well as its representation in Stoker's narrative production about Ireland's folklore. In particular, Cadeddu refers to the violent nature of Irish traditions, which are based on discontinuity rather than stability and conservatism, as is usually the case with folkloric discourses (37). His acute examination of the common memory of Irish narratives of tradition allows him to observe in Stoker the goal of preserving the national identities of the past and while consolidating them with modernization in order to create - or imagine - a thriving and independent future.

Anjili Babbar and Rebecca Long follow similar lines of argumentation in their respective chapters ( 3 and 4 ) to discuss oral tradition and music as an essential part of Irish folklore. While the first uses the literature of Frank Delaney to explore the relevance of subjectivity in the production of historical discourses, not only in the oral tradition but also in the narrative attempts to reconcile orality and written historical accounts, the second also focuses on subjectivity to discuss the "performative nature of story and music" (53) to unveil cultural constructs and reimaginations of tradition. Both authors agree about how the inquisitiveness of Kate Thompson and Frank Delaney manifests an urge to find new ways of reimagining and regenerating the key events in Irish tradition, a practice that would both reinforce and renovate the production of folkloric identifications.

There is yet another set of contributions in this volume that study music as one of the most important components of Irish folklore. Chapter 5 introduces Maria Byrne's intertextual approach to Valse Shilly Shally, "an Irish expression of the Viennese Waltz" (65). Although the editors claim in their introduction that "many scholars have been historically frustrated by Ireland's failure to produce an internationally renowned composer whose language imbues that of 'traditional' forms of Irish music" (6), they also recognize that Byrnes' exploration of Harry Hardy's idiosyncratic assemblage of Irish dances and melodies opens new - and innovative - forms of research about the impact of Irish music on mid-nineteenth-century recollection of traditions, particularly from the perspective of the band of the Royal Irish 
Constabulary. This chapter evidences an appropriate research methodology, based on the author's use of newspaper archives.

In "Musical Interpretations of Fenian Literature by Contemporary Irish Composers", Angela Horgann Goff also pays attention to the connections between folklore and music. The writer approaches the correlation between cultural discourses and the production of identity to explore contemporary musical revisions of major episodes from the Fenian Cycle. Her examination of Tír na nÓg-inspired works by composers Philip Hammond, Eric Sweeney, and Elaine Agnew - considering the differences in each composer's stylistic construction provides a musical and textual analysis that reflects the timelessness of the Fenian tales. Horgann Goff successfully links the pluralistic interest of these creators in this discourse of Irish folklore to the recent attention - from both scholars and general audiences - to the connections between literary and musical traditions. The author ends her chapter with a reflection on the operation of folklore and its impact on contemporary identifications, claiming that "... the eclectic responses to the tale do not expunge musical 'Irishness'; rather, they embed it in an evolving modern Irish cultural context" (98).

Although the contributions in this collection offer an intersectional and transdisciplinary approach in most cases, the structure of the book lets the reader go from a theoretical chapter about folklorism to two blocks of essays which are centered, respectively, in literature (chapters 2, 3 and 4) and music (chapters 5 and 6). After these first glimpses of folklore through a literary and musical lens, the second part of the book offers a compendium of studies centered on cultural discourses and diverse - and still transdisciplinary focalizations: drama, film, and cultural studies.

Chapter 7, by Daithí Kearney, studies the articulation of music and drama through the themes of Samhain and Hallowe'en, and he pays particular attention to two different performances, both entitled Samhain, produced by Siamsa Tíre, The National Folk Theatre of Ireland. Based on the form of folkloric theatre, including song, dance, and music, these performances draw inspiration from the past, according to Kearney, to provide relevant significance to a contemporary audience (100), and have therefore a high pedagogical interest through the use of folkloric elements to engage modern audiences.

In "From Page to Stage and Beyond: (Re)Imagining Cré na Cille," Eilís Ní Dhúill presents a comparative study, as her title indicates, of Máirtín Ó Cadhain's novel (1949) for various stage adaptations and one for film in 2006. Focusing on the power of memory, the author looks at these adaptations of the novel as they reflect on the transmission of cultural traditions to younger generations, who reinterpret storytelling through (post)modern performances.

Intergenerational communication through film is also the subject of Jack Casey's contribution on "Mother Ireland: Folklore and the Fractured Family in Irish-Themed Cinema" (Chapter 9). The author examines four Irish films produced in the last twenty- five years (Into the West, The Secret of Roan Inish, A Shine of Rainbows, and Ondine) through a lens directed at the folkloric transmission of the mother in Ireland as cultural icon, and how it is being reconstructed from a multicultural point of view.

Chapters 8 and 9 are therefore interested in looking at the possibilities of adapting folklore to contemporary times with the use of non-traditional narrative forms. Such adaptations should be interpreted as a effort in the conservation and reconceptualization of the discourse that create a particular set of identities and identifications, in this case in the area of Irish folklore. These contributions are consistent with Ben Simon's in "Discovering and Celebrating Ireland's Tree Folklore", the final chapter of this collection. Simon's exquisite research into the cultural discourses produced by and around trees in Irish folklore enhances the critical aspirations of this book. Here again traditional diverse forms of narrative are read from a renovating perspective to keep telling things about Irish identities, not only from the 
past but also in their modern-day forms. For example, Simon refers to "The Forest of Belfast," an urban project (1990-2014) created to encourage "a tree culture" among citizens that investigated the veiled oral narratives - and cartographies - around specific trees and types of trees, which encapsulated living traditions and folklore themes.

This collection of essays succeeds in compiling a set of current foci of folklore studies in Ireland, and offers a variety of insightful perspectives on the subject. Directly drawing on Locating Irish Folklore: Tradition, Modernity, Identity, the famous study authored by Diarmuid Ó Giolláin, leading voice in Irish folklore studies and one of the contributors to the present volume, New Crops, Old Fields successfully fills the gap in the contemporary study of Irish traditions and folklore from a transnational, transdisciplinary, and cultural perspective. Intended for a scholarly audience with expertise in Irish folklore studies, the editors of this volume provide an interesting and stimulating composition that brings together the new explicitness of the Irish cultural sphere, explained through discourses of diversity, migrations, and globalization, and the traditions that inform its connection to the folkloric past. I am convinced that this book will open up new lines of research into the treatment of Irish folklore. Its emphasis on the relevance of new forms of looking at traditions opens new windows to the study of Irish identities. This call for further research is a testimony to Caldwell and Byer's success in their captivating volume.

\section{Works Cited}

Anderson, Benedict. Imagined Communities. London: Verso, 1983.

Bhabha, Homi K. "Introduction". Nation and Narration, ed. Homi K. Bhabha. London: Routledge, 2000. 1-8.

Flannery, Eóin. Ireland and Postcolonial Studies. Theory, Discourse, Utopia. London: Palgrave McMillan, 2009.

Graham, Colin, and Richard Kirkland, eds. Ireland and Cultural Theory: The Mechanics of Authenticity. London: Macmillan, 1999.

Kiberd, Declan. Inventing Ireland: The Literature of the Modern Nation. London: Vintage, 1996.

Ó Giolláin, Diarmuid. Locating Irish Folklore: Tradition, Modernity, Identity. Cork: Cork University Press, 2000.

Pine, Richard. The Disappointed Bridge: Ireland and the Post-Colonial World. Newcastle: Cambridge Scholars Publishing, 2014.

Eduardo Barros-Grela is an Associate Professor in the Department of English at A Coruna University (Spain). He is interested in cultural studies, inorganic bodies and spaces, visual studies, and the dialectics of representation and performance. Recent publications include studies of violence in contemporary film and literature, and studies on Irish culture.

ebarros@udc.es 
Flann O'Brien: Problems with Authority.

Edited by Ruben Borg, Paul Fagan and John McCourt.

Cork: Cork University Press, 2017. 330 pp.

ISBN: 978-1-78205-230-2

\section{Reviewer: Germán Asensio Peral (University of Almería, Spain)}

Flann O'Brien: Problems with Authority purports to examine the concept of authority as applied to Irish writer Brian O'Nolan/Flann O'Brien/Myles na gCopaleen. In their Introduction, the editors advance the volume's intention "to make a pitch for a mode of inquiry more finely attuned to the multifacetedness and prodigality of the writer's riotous imagination in its own inveterate questioning of fixed positions and commonplaces" (9). Furthermore, the introduction traces O'Nolan's history of both authoritarian, mockauthoritarian and anti-authoritarian rhetoric throughout his oeuvre, starting with Blather (the short-lived journal co-founded in 1934 with his brother Ciarán and lifelong friend Niall Sheridan), to his long-lasting Irish Times column Cruiskeen Lawn (1940-1966), noting his "knack for dissecting the spurious authorities of institutions" (6) and his ability to write "against the weight of received wisdoms [and] inherited sureties" (8). The volume is thus arranged in a thematic way; divided into three heterogeneous parts, each with five individual chapters thematically resonant with each part as a whole.

The volume's opening section, “"neither popular nor profitable': O'Nolan vs. The Plain People" pits O'Nolan's work against the popular and common, thus magicking him away from the elevated modernist and post-modernist pedestal where he normally stands under the eyes of academic scrutiny. Carol Taaffe's essay opens the section by building on her seminal Ireland Through the Looking-glass: Flann O'Brien, Myles na gCopaleen and Irish Cultural Debate (2008) by displacing him from a generally perceived status as a selfappointed knight of the Dublin intelligentsia, conversely remarking his "instinct to orientate himself towards the daily press rather than the world of the limited edition" (33). She sees Blather, Cruiskeen Lawn and the pieces published in The Bell as challenges to Ireland's social and cultural conservatism of the mid-twentieth century. Taaffe argues that these are examples of O'Nolan's democratic, therefore anti-authoritarian, energies as a writer, and are, in turn translated into never-ending dialogue with the public sphere. In the same vein, Maebh Long's chapter makes a compelling case to see some of O'Nolan's works - Blather, Cruiskeen Lawn and his plays and teleplays - as predominantly engaged with Irish popular culture. She contends that O'Nolan wields rather than discards cliché in an attempt to show that "the stereotype has so long interacted with national and international senses of Irish identity that the real was always contaminated, and O'Nolan is authentically representing the already inauthentic" (49). Consequently, these works can be understood as openly criticizing how post-independence Ireland bizarrely embraced the Wildean notion of life imitating art, thus concluding that Irish identity was partly driven to performance and inauthenticity. Maria Kager switches the focus to the linguistic realm but retains the interest in the popular sphere by examining O'Nolan's representation of Irish localisms, clichés, poor or ungrammatical language and accents in the early bilingual or multilingual Cruiskeen Lawn columns. By employing neurolinguistics and psycholinguistics as a theoretical background, Kager interestingly brings to the fore how O'Nolan's bilingualism might have resulted in heightened metalinguistic awareness. Similarly, Catherine Flynn expands on O'Nolan's multilingual interests while adding a pinch of the political to the mix. In her illuminating essay, Flynn addresses a set of Irish-language Cruiskeen Lawn columns dealing with the role of Japan in the Second World War and discloses O'Nolan's intention to indicate the existence of political and linguistic similarities between Japan and Ireland through what she shrewdly terms as "an 
aesthetics of the half-said" (72). She notes that the attention devoted to Japan in Cruiskeen Lawn served to "lead readers to consider the position of Ireland in world politics, while offering oblique commentary on the Irish state's own territorial policies, all the while evading strict wartime press censorship" (72). Katherine Ebury closes the section with an intriguing essay on O'Nolan and the popularization of science - Einstein's physics in particular through the figures of Arthur Eddington and Sir James Jeans, who were prone to literary allusions to bodily distortions so as to make explanations more accessible and closer to popular religious views. Ebury looks at O'Nolan's Cruiskeen Lawn, The Third Policeman and The Dalkey Archive and observes the changing dynamics of O'Nolan's reception, and the reversion to the authority posed by said popularizations by comparing the representation of bodily distortions in these works. She concludes "O'Nolan treats self-critique by Jeans and Eddington, and equally their attempts to reconcile science and faith, as material for satire" (102).

Part II, "Mixed Inks: O’Nolan vs. his Peers" situates O'Nolan in the context of twentieth-century writing, both Irish and European, and offers well-thought comparisons with local and international authors writing in English, Irish and Italian. Dirk Van Hulle's essay on the models of cognition depicted in works by Joyce, Beckett and O'Nolan challenges more typical assessments of O'Nolan's work as a postmodernist. He nests The Third Policeman and "John Duffy's Brother" inside a "continuum between modernism and late modernism" (118) due to their performance of what he terms as Umwelt research; that is, studying how organisms perceive their surroundings. For Van Hulle, the use of the Umwelt model in these novels is evidence of O'Nolan being halfway between Joyce's modernism and Beckett's late modernism. Ronan Crowley diverts attention towards the Irish Revival and O'Nolan's protean qualities in terms of his use of pseudonyms. Traditionally, the Irish Revival has been read as an inherently anti-modernist movement, a notion that could be induced from O'Nolan's satire-clad thoughts on the Revival. By overviewing the Revival's literary bloodline and its constant recourse to pseudonymity, Crowley argues that O'Nolan is deeply nested in the Revival tradition precisely because of his creation of many literary personas. He convincingly suggests that "rather than the mugging of the funny-man, his practice of employing pseudonyms should be recognized as part of a dialectic internal to the broader Revival" (134135). Next, R. W. Malsen puts forth a comparative study between James Stephen's The Crock of Gold (1912) and O'Nolan's The Third Policeman. He expertly detects the political undercurrents running through both texts, and advances his argument that O'Nolan turns the amiable and hopeful post-independence Irish utopia of Stephen's novel into a dismal metaphor of an Ireland infected by the authoritarian political trends played out in Germany and Italy. Most importantly, Malsen notes 'O'Nolan's decision . . . to redraft Stephen's book in the context of the nationalist ferment that preceded the Second World War can itself be seen as a political act" (137). Ian Ó Caoimh's essay examines the incongruities between Ciarán Ó Nuallain's Óige an Dearthár .i. Myles na gCopaleen (1973), Anthony Cronin's biography No Laughing Matter: The Life and Times of Flann O'Brien (1989) and the representation of the Gaeltacht in O'Nolan's An Béal Bocht (1941) and Irish mythology and folklore in At Swim-Two-Birds. Ó Caoimh's meticulous examination of Cronin's translation of certain passages from Ciarán's biographical account reveals that they were mistranslated or misinterpreted, noting that "clearly, Cronin's translation from Ciarán's Irish source tends towards the baroque" (161). John McCourt's essay closes the section with a close examination of The Hard Life and the chapters that cover Collopy, Father Fahrt and Manus' trip to Rome. McCourt takes up the theme of squalor, which is central to the novel, and suggests that O'Nolan used it as a platform from which to make fun of literary and religious authority while acknowledging that "the reality is that its confrontation with authority clerical and lay - is underpowered" (171). 
Part III is titled "Gross Impieties: O'Nolan vs. the Sacred Texts". This final section of the volume concerns O'Nolan's debunking, deconstruction or whimsical alteration of the authorities of the past. Louis de Paor's opening essay delves into O'Nolan's university years and his MA thesis on nature in Irish poetry, with the aim of determining to what extent did early Gaelic literature and contemporary translations of crucial Irish language texts influence both his bilingualism and future writing. De Paor considers their relationship to bilingualism to exemplify Roland Barthes' notion of 'unalienated language' - "The dream of an unalienated language is a defining element of Brian Ó Nualláin's writing, intensified by his knowledge of pre-colonial Gaelic Irish literature and his own ambiguous relationship with the Irish language" (203). Alana Gillespie's fascinating essay sheds new light on At Swim-TwoBirds and The Dalkey Archive by drawing on theories of tradition and the past by Walter Benjamin and Jacques Derrida. She examines how O'Nolan's novels both deconstruct and redesign myths, sacred texts and received narratives while at the same time reaffirming the presence and duty of the reader: "O'Nolan calls attention to authors' and readers' shared responsibility to sift, choose and reaffirm, to inhabit a narrative willfully" (218). Ruben Borg continues the trend of signaling O'Nolan's simultaneously modernist and traditionalist discourse by summoning the conversion of Paul the Apostle as a context in which to understand the ambiguities at the heart of his literary identification. He pinpoints the death-inlife motif in The Dalkey Archive, Cruiskeen Lawn and "Two in One" and Paul's paradoxical neither/nor-but-both-at-once attitude towards the persecution of Christians and Christianity. Borg marks O'Nolan's “invention of a new way of being the world ... by which one belongs to and sets oneself apart from the authority of the past" (229). Dieter Fuchs takes a welltrodden direction with his essay on The Dalkey Archive and its Menippean satirical elements. The essay overviews the Menippean tradition and reads O'Nolan's last completed novel as a satire in which Mick resists and overcomes religious, philosophical, artistic, scientific and administrative authority but is confronted at the end with an impending brand of matriarchal authority. In truly Menippean fashion, Fuchs contemplates the conclusion of the book in an open-ended way - "a reading of O'Nolan's book results in the Socratic insight that all that one knows is that one knows that one knows nothing" (241). Tamara Radak's chapter closes the collection with a thought-provoking dissection of the use of footnotes in The Third Policeman and their distortion of temporal, spatial and narrative "authorities". Supported by a solid critical background (Deleuze, Todorov, hypertext theory and possible worlds theory), she sees the novel's flashing and intentionally confusing hypertexts as the source of "multiple pathways that lead to different possible worlds as well as a surplus of possible meanings that can never be completely exhausted" (254).

Flann O'Brien: Problems with Authority is overall an invigorating, thematically sound book. Its scope is ample enough to cover a wide swath of O'Nolan's work (including as yet unchartered waters such as his MA Thesis and Blather), even though the book could have benefitted from dedicated study of O'Nolan's plays and teleplays on a number of occasions, most notably in Parts I and II. While it was partly inspired by the proceedings of Problems with Authority: The II International Flann O'Brien Conference, held at Università Roma Tre in 2013, the essays that compose the collection are nevertheless critically up-to-date and follow consistently the current trend of O'Nolan studies kickstarted during the early 2010s with the founding of the International Flann O'Brien Society and the plethora of book-length contributions and academic articles on the author to have appeared in recent decades.

German Asensio Peral obtained his bachelor's degree and Master's Degree in English Studies at the University of Almería (Spain) with an honorary distinction. He is currently working on his Ph.D. dissertation on Brian O'Nolan and his journalistic production as Myles na gCopaleen. He is a Research Fellow at the University of Almería (Department of 
Philology), focusing on Irish literature, and has published and delivered papers on O'Nolan's work.

german.asensio@ual.es

Kate O'Brien and Spanish Literary Culture.

Jane Davison.

Syracuse: Syracuse University Press, 2017. 208 pp.

ISBN: 978-08156-3547-5

\section{Reviewer: Verónica Membrive Pérez (University of Almería, Spain)}

The publication of a special issue of the journal Irish University Review devoted to Kate O'Brien, together with the online broadcast of poet and editor John Gawsworth's BBC 1970 short documentary which contains valuable footage of the Limerick writer, leads to the assumption that there is still much to be explored about O'Brien and her literary production. Kate O'Brien and Spanish Literary Culture by Jane Davison supports this perception since it certainly puts forward an original and previously neglected approach to the works of the Irish writer. Kate O'Brien's conception of Ireland in her fiction is inextricably linked with her experience abroad, particularly in Spain, and this space would become her locus of cosmopolitanism to the same extent that Paris, London or Trieste would be for Beckett, Bowen and Joyce respectively, who left Ireland "to live and work in capital cities of international modernism" (Pearson 2). In all cases, their discourse of cosmopolitanism was never separated from their assessment and reassessment of the turbulent establishment of the Irish Free State and the resulting paralysis of the Irish cultural scene. Certainly, Kate O'Brien's relationship with Spain has been studied from several perspectives. Researchers such as Lorna Reynolds, Adele Dalsimier, Eibhear Walshe, Aintzane Legarreta Mentxaka, and Ute Mittermaier have underscored the importance to O'Brien's fiction of her Iberian experience during the 1920s and 1930s, and especially her time in Bilbao. Her novels Mary Lavelle (1936) and That Lady (1946) are set in Spain and her love for the country also resulted in the publication of the travel journal Farewell Spain (1937), just after the outbreak of the Spanish Civil War. In this monograph, based on her PhD dissertation, Davison delves into specific Spanish authors' plays, fiction, and even letters as a conduit to a detailed exploration of O'Brien's influences from Spanish at that time, but as far back as the $16^{\text {th }}$ century. In particular, the book offers a comprehensive comparative analysis of her writings with that of influential Spanish writers Jacinto Benavente (1866-1954), Miguel de Cervantes (1547-1616) and Catholic mystic Saint Teresa of Avila (1515-1582).

The first chapter focuses on the examination of Benavente's plays of the turn of the $20^{\text {th }}$ century in relation to O'Brien's novels Without my Cloak (1931) and That Lady (1946). Davison's selection of Benavente's plays El Hombrecito (1903) and Princesa Bebé (1906) is apt for the purpose of this research because both the novels and the plays are concerned with the struggles of women with morality and individuality and contain insight into societal views of "the function of marriage and family, morality and duty versus desire" (45). This chapter illuminatingly aligns Benavente's fictional characters Nené and Princess Helena with O'Brien's Denis, Caroline and historical figure Ana de Mendoza, as rebellious women who defy or challenge the moral code of their social class, thus drawing a connection between 
O'Brien's Mellick (her fictional rendering of her home place, Limerick) and Benavente's Spain from a female perspective in terms of the inequality and discrimination rife in both places. The Spanish Nobel Prize winner was one of the few writers from the Generation of '98 who wanted to promote Spain's place in the world after the loss of its glorious imperial past. This study suggests that O'Brien's link with Benavente came from her interest in becoming a playwright at the beginning of her career and also from her contact with the Starkie family, in particular from her alleged personal relationship with Enid and her brother, the Hispanist Walter Starkie, who published a dissertation on Benavente in 1924. Davison explores Walter Starkie's promotion of the Nobel Prize winner's plays in Ireland during his years as the director of the Abbey Theatre (1927-1942), and the utter rejection by The Abbey of any foreign influences in the cultural environment of the Free State. Starkie would become another Irish writer who, like O'Brien, was fascinated by Spain and who travelled back and forth to the country until his death in 1976. Although Davison's comparative analysis is enlightening, a more thorough research of O'Brien's debut play Distinguished Villa: A Play in Three Acts (1926), which is briefly mentioned, would have been very revealing, considering the author's recurring concern with the "behavioural norms and sexual predilections of the English middle-classes, and her early awareness of the requirements of the British censor" (Moran 7).

Chapter 2 elaborates on the influence of the most prominent work in the Spanish language, Cervantes's Don Quixote, mainly on O'Brien's novels Mary Lavelle (1936) and Pray for the Wanderer (1938). Through a detailed analysis of several main and secondary characters, Davison profiles the multifaceted reception of Cervantes's chivalric novel on O'Brien's aesthetic development and her relationship with the literary stagnation that was taking place in her native country. Of particular interest is Davison's aim to establish a correlation between Cervantes and O'Brien's shared Erasmian concept of interiority and individuality, as well as their witty and sharp approach to escape censorship through the enactment of oblique references to the issues considered subversive during both the $16^{\text {th }}$ century and the first decades of the $20^{\text {th }}$ century in De Valera's Ireland. O'Brien experienced the banning of Mary Lavelle, so she would have searched for a new means of circumventing the Irish Censorship Board when writing her next novel, Pray for the Wanderer, published two years later. She wanted to give the impression of having "learned the lesson" derived from the 1937 Constitution through the character of Una by outlining the embodiment of the docile, innocent female character meant for domestic life that was expected in independent Ireland.

The last section of this book focuses on the figure of the mystic and writer Saint Teresa of Avila, whose writings permeated O'Brien's whole literary production, to the point that the Irish writer published a study of the saint in 1951. As the chapter progresses, it is revealed how O'Brien's female characters, especially in The Flower of May (1953) and That Lady (1946), are coded in order to be given a sense of "self-government and individualism that was denied to the female citizens of Éamon de Valera's Ireland" (110), and were clearly influenced by the controversial reformer of the Carmelite Order and her interpretation as an representative figure for lesbianism and feminism. As was the case with Cervantes, Teresa of Avila also influenced O'Brien through the avoidance of obvious references to taboo topics, preferring the use of subtextual meanings instead. Considering O'Brien's utter rejection of Ireland's parochialism and exacerbated promotion of the national myths that permeated all social and cultural spheres after the country finally accomplished its independence, it is certainly not unusual that the Irish writer declared her condemnation of Franco's regime in her travel journal published just after the outbreak of the Civil War. O'Brien preferred Spanish Catholicism to that of the Irish variety because it was totally opposed to puritanism 
being established in her home country, although after Spain's Civil War that version of Catholicism which O'Brien admired would become a thing of the past.

In sum, this study reinforces the impact that O'Brien's formative period in Spain in the 1920s and 1930s had on her works and Davison's perspective bursts with originality. Considering that there is a continuing need to reassess O'Brien's status within the Irish literary canon, this book proves invaluable in contributing to our understanding of the Irish writer's struggles to be heard, to bear witness, and to preserve her personal freedom while describing the social, political and cultural atmosphere of both Ireland and Spain. It could be asserted that Kate O'Brien has been well served by this scholarly monograph.

\section{Works Cited}

Moran, James. "Kate O’Brien in the Theatre." Irish University Review 48.1 (2018): 7-22.

Pearson, Nels. Irish Cosmopolitanism. Location and Dislocation in James Joyce, Elizabeth Bowen, and Samuel Beckett. Florida: University Press of Florida, 2015.

Verónica Membrive Pérez earned a Master's Degree in English Studies in 2011. She completed her Ph.D. at the University of Almería (2017) on Irish travel writers in Spain during the twentieth-century, and has delivered papers on Walter Starkie, Kate O'Brien and Pearse Hutchinson and their Spanish travels. She is currently teaching English at the University of Almería. Her field of research is Irish Literature, with a special focus on the relationships between Ireland and Spain. She has been recently awarded with the George Campbell Research Award by the University of Málaga.

v.membrive@ual.es

Stinging Fly Stories.

Edited by Sarah Gilmartin and Declan Meade.

Dublin: The Stinging Fly Press, 2018.

ISBN: 978-1906539696

Reviewer: Ángela Rivera Izquierdo (University of Granada, Spain)

It has been 20 years since The Stinging Fly, one of Ireland's most best-known literary periodicals, published its first issue back in March 1998. To celebrate the occasion, a retrospective anthology entitled Stinging Fly Stories has been released, containing a selection of 40 stories by 40 different writers. Since it was founded in late 1997, the aim of the journal has been to publish the best new writing, promoting particularly the short story form. Coedited by The Fly's founding editor and publisher Declan Meade and critic Sarah Gilmartin, the collection includes stories by both newcomers and now well-established writers, such as the inaugural trio formed by Colin Barrett, Kevin Barry and Sara Baume. Ordered alphabetically by the author's surname, and without specifying date of publication, these stories are multifarious in nature, written by Irish and international authors who have chosen wide-ranging themes and settings for their work.

As Sarah Gilmartin notes in her introduction, "most of the stories focus on a single moment of crisis in one character's life - the lonely voice calling out". Indeed, loners and social outcasts populate this anthology. In Colin Barrett's "Let's Go Kill Ourselves" an 
estranged college student returns to his small Irish home-town for Christmas. An encounter with an acquaintance from his adolescence triggers memories of juvenile violence and thoughtless cruelty. This early story appears to be an embryonic version of Barrett's Young Skins (2013). Kevin Barry's "Last Days of the Buffalo", featuring an emotionally bereft giant, captivates from the very beginning with its vigorous and categorical opening line "...our towns are sexed". After losing his job at a local petrol station, phagocytised by a multinational, the enigmatic protagonist seeks peace in his daily jaunts into the countryside. Barry's evocative prose is peppered with spellbinding lyricism and lurid vernacular. He is a masterly craftsman, endowing the text with vivid descriptions of the Limerick landscape - a blend of the mundane and the uncanny that borders magical realism.

Female characters suffer from emotional numbness in Lucy Sweeney Byrne's "Danny" and Nicole Flattery's "Hump". Byrne's protagonist, a "Frankenstein's monster of a person, filled with immiscible contradictions and self-loathing", voices the quarter-life crisis of an increasingly disenchanted youth. The story exposes the superficial progressivism of many youngsters whose claims to artistic and intellectual superiority vis-à-vis their parents does not necessarily entail a greater sensitivity and can even mask inexorable callousness. Cynicism and obsessiveness define Flattery's nearly sociopathic loner, whose repressed grief manifests itself somatically. Surprisingly, it is virtually impossible not to feel sympathy for this poor wretch: "This is hilarious. No, actually, this is an illness. This inability to take anything seriously. I should get money from the state". This is a laugh-out-loud funny story, which shows sardonic wit and a wicked sense of humour. On a similar note are Colin Corrigan's "Deep Fat" and Philip Ó Ceallaigh's "The Beast". The former is an absurdly wonderful oddity concerning an unemployed man's fixation with making perfect chips. It is quirky, savage and darkly comic. The latter is a Hobbesian tale of ruthless competition between two paranoid elderly neighbours over the ownership of a peculiar rodent. It hints at the misanthropic pessimism and harshness, but also the compassion that characterises many stories by this brilliant writer. Equally formidable is Claire-Louise Bennet's "Finishing Touch", a domestic tale reminiscent of Virginia Woolf or Katherine Mansfield, of a woman "determined to host a low-key, but impeccably conceived, soiree." Bennet's first-person narration evinces a superlative control of voice that offers intense introspection, making this non-epiphanic, almost plot-less story both eccentrically absorbing and singularly discomforting; an intrusive glimpse into the ruminations, ramblings and compulsions of a well-nigh neurotic psyche.

Yet more elderly protagonists reassess their lives in Michael J. Farrell's "Pascal's Wager" and Nora Pyne's "Jeopardy". Farrell's is a beautifully poignant story about a man's escape from his nursing home and the need to fulfil a longstanding, self-imposed promise. Rich in religious and philosophical overtones, it is a humorous and heartfelt exploration of the possibility of transcendence, and the eager desire to do right brought on by the proximity of death: "Pascal's Wager was more than an intellectual exercise. "To be quite frank about it, a man with an immortal soul needed to cover his arse." "Jeopardy" recounts the raptures and ruptures of a fervent Christian widow, whose long life has been profoundly affected by sexual repression and tamed desire due to the restrictions placed by patriarchy upon women. The residue of strict rules of decorum and puritan morality also permeates Grace Jolliffe's "Becoming Invisible" in which a demure, fifty-five-year-old woman becomes suddenly aware of her sexuality.

There are also stories of teenaged and childhood bewilderment in this outstanding collection. In Oisín Fagan's blatantly graphic and brutal "Jessie", a wannabe macho man is appalled by a teenage girl's ghastly disclosure. The protagonist's perplexity touches deeply and is incredibly contagious. Sinéad Morrissey's “The Day I Brought Water" captures 
sublimely the unawareness and vulnerability of childhood through an elegant interweaving of parallel narratives in which the reader must unravel the clues of a traumatic puzzle.

"Trouble knows its way around", claims Kavanagh rightly in Danielle McLaughlin's "Night of the Silver Fox", a harrowing depiction of how desperate times call for desperate measures, set against the backdrop of Ireland's economic recession. It shares its bleak ambience and nail-biting suspense with Carys Davies's "The Quiet", a gripping, unpredictable piece about a woman's seclusion in her countryside dwelling and the dreaded visit of a sinister neighbour. The story's eerie tone and atmosphere convey a sense of anguish and looming threat that can only keep the reader intrigued and engrossed.

Loss and desolation pervade Sara Baume's heartrending story "Fifty Year Winter" in which the narrator's father faces the death of his beloved wife and dog. Baume has a unique eye for describing the natural world and her use of language is exquisitely poetic and playful. It has a melodic quality to it, proving skilled use of alliteration and repetition of choruses which infuse the narrative with an unrelenting beat: "I'm standing on the cracked concrete slabs of the graveyard, between the polished granite and Celtic crosses, the plastic bouquets and green glass gravel, when I realise it will be just my father and me for Christmas this year, and the dog, who is not dead yet". Coping with loss is also central to Claire Keegan's "Dark Horses", an oneiric, equine story that revolves around a mild alcoholic's dejection and unbearable regret after losing his loved one. Its acute Irish sense of place and rendering of pub culture aligns it with Lisa McInerney's "The Butcher's Apron” a dazzling and satiric narrative of an unwanted flag and the irreconcilable past that looks into the power of symbolism and the dangers of the exhilaration of ecstatic camaraderie: "...tactics need to be charmed out, whetted by emphatic reminders of their history, of the times that bind compatriots. Reminiscence is a virus hopping from host to host and strengthening".

Infidelity is clearly a major theme in this compilation. Marriages on the edge are central in Jennifer Brady's “Ten Days Counting Slowly", Mary Costello's "Things I See", Molly McCloskey's "Pixels" and Sean O'Reilly's "All Day and All of the Night", all of which render marital shortcomings with uncomfortable honesty. Particularly outstanding is Leona Lee Cully's “A Sin To Tell the Naked Truth", an erotic and visceral account of sex and/as consumption, dealing with inherited deceit and the adulterous encounter of a loving mother and unfulfilled wife: "She knew it would turn her on to wear it, to play the prostitute, play with the porn stereotypes, take pleasure from violating her own rage at them. Her husband would say, you look like a whore, you're a mother for God's sake, you look ridiculous, and he would laugh but still want to fuck her".

All the stories in this anthology are priceless gems, showcasing a wide variety of voices and offering a compelling look at the human condition. "The power of a short story lies in writing that makes fictional worlds read true, writing that creates intimacy between the reader and characters 'living' on the page", Sarah Gilmartin comments. These stories are surely a reality bump, stories that take you inside, capable of destabilising you while simultaneously making you feel less lonely and more sympathetic, in this bewitchingly chaotic universe. As Aldous Huxley put it in Brave New World, "Words can be like X-rays if you use them properly - they'll go through anything. You read and you're pierced". Without offering great revelations or existential solutions these tales of ordinary people in desperate situations will not leave anyone indifferent.

Ángela Rivera Izquierdo is a $\mathrm{PhD}$ student in English Literature at the University of Granada. She is particularly interested in Scottish and Irish fiction, approached from the theoretical framework of Gender Studies and post-phenomenological communitarian theory. 
angelarivera@correo.ugr.es

\section{Bloodroot.}

Annemarie Ní Churreáin.

Aille, Inverin: Doire Press, 2017. 71pp.

ISBN 978-1-907682-58-2

\section{Reviewer: Manuela Palacios González (University of Santiago de Compostela, Spain)}

Bloodroot, a plant with underground rhizomes which secretes red sap when cut, is a most appropriate trope for the expression of a wounded subjectivity that exudes pain and anger through memories of women's dispossession of their bodies, their children and their dreams. Annemarie Ní Churreáin's debut collection, Bloodroot, was written "as a form of revolt against the push and shove and thrust of a deeply patriarchal society" ("I Was Raised"). This explicit feminist statement should make us wary of siren songs about the advent of a postfeminist age in which women's rights are no longer at issue since, as late as 2017, Bloodroot exposes the persistence of open wounds and inherited traumas inflicted by a patriarchy on women's sexual and reproductive lives.

Ní Churreáin's book consists of three parts, the first of which contains the title poem, "Bloodroot", with a dramatic monologue in which nobody seems to answer or even hear the poetic persona's questions. Set at the Castlepollard Mother and Baby Home, the poem engages with the taboo around women's socially inconvenient pregnancies -

Doors if I stitch you a collar of lace all Spring as I wait for the first-born

heat please, won't you open and speak? (24)

Ní Churreáin writes polyphonic verse and thereby allows formerly silenced voices to be heard. The overt political denunciation of the Irish State's repressive policies is not at odds with the poet's craft. On the contrary, Ní Churreáin excels at the subtle blend of place, subjectivity and engagé poetry as she delves into "the relationship between landscape and lyrical control ... between the place I physically come from and the State in which I, as a woman in Ireland today, now exist" ("I Was Raised").

A recurrent topic in Irish literature and criticism is that of "sense of place" and one may wonder about the possible intersections of rootedness and gender. Many are the poems in Bloodroot that present nature as the primary stimulus to write, as is the case of the first poem in the collection, "Untitled" -

Badger trails called me aside for a word.

Come underground, they said.

See what we are made of' (13)

or the poem "Doire Chonaire" -

To you I owe my hunger. For metaphor

is a failed attempt to speak in common terms" (22)

Ní Churreáin's verse playfully melds, by means of adept caesura and line break, the yearning for writing and the allure of landscape. The gender perspective, however, is made explicit in poems such as "Border" ("women / who like me possess the earth // in their eyes", 26) in 
which the landscape is embodied and the female poetic persona enacts the repossession of the lost land while reflecting upon the scar left by the border on the distaff genealogy. A similarly gendered sense of place pervades "Family Law", in which Ní Churreáin appropriates the ancient Ogham language and its tree alphabet to refute a Christian discourse about women's inferior and culpable condition -

But daughter, we come from the spriest woods.

You and I are the roots

that uphold an alphabet to the sun.

Your name begins in Ruis, mine in Ailm (31)

Not surprisingly, the Galician poet Marilar Aleixandre also chose this tree alphabet as the central motif of her collection abecedario das árbores [a b c of trees] (2006) so as to forge bonds between the two Atlantic communities, their landscapes, their vernacular languages and their women -

\author{
foi nas silveiras \\ gardastes a lingua cruzastes \\ as mans nas costas \\ talvez porque non queriamos negar \\ a herdanza das bruxas (48; note below)
}

The second part of the collection has a significant focus on the disciplined, punished and incarcerated body, thus illustrating Ní Churreáin's interest in "placing the body back at the centre of human experience, placing human experience back at the centre of the State" ("I Was Raised"). The dismembered body is "thrown up out of the underworld" in "The Kerry Foot" (35), very much like those unacceptable truths which, though deeply buried in the unconscious, resurface again and again as in Sigmund Freud's return of the repressed. Myth and daily life entwine to convey a long and interminable history in the oppression of women, although the reference to the legendary Sadhbh also allows for a degree of feminine empowerment and self-defence:

This was the fortune foot of Saidhbhín,

who set a hoof

into the centre of a soldier's fort

to win her human body back.

One touch of the earth

and the hide fell

from her bones.

Reality and fantasy, the conscious and the unconscious, the physicality of the chastised body and the discarnate nightmare confer a surrealistic mood upon the second part of Bloodroot that recalls Buñuel's and Dali's film Un chien andalou (1929) - especially so in poems such as "Saidhbhín" - probably because Catholic Spain and Ireland have lived under comparable moral strictures. The recourse to myth and the oneiric alongside quotidian reality is a characteristic feature of Irish poetry that we find in other women writers such as Nuala Ní Dhomhnaill - her poem "An Bhatráil" [The Battering] from The Astrakhan Cloak (1992) comes to mind as another poignant rendering of tortured motherhood. Paula Meehan's "The Statue of the Virgin at Granard Speaks" from The Man Who Was Marked by Winter (1991) is 
also recalled as we read Ní Churreáin's "The Secret", both being poems about the fifteenyear-old girl who died giving birth close to a statue of the Virgin at Granard in 1984. If Meehan gives a voice to a contrite Virgin Mary, Ní Churreáin seems to locate her poetic persona in Ann Lovett's place as she closes the poem with the questions: "What can I do? Who to tell?" (42). These examples of intertextuality evince a genealogy of Irish women writers whose legacy Ní Churreáin has taken up with admirable mastery and sensibility.

Part III of Bloodroot undertakes a voyage out: out of Ireland so as to discover other hospitable landscapes in America and in Asia; out of a tortuous past so as to pave the road towards more auspicious days. After the trauma and the telling there comes the time for reconstruction. Residual pain persists but is soothed by love, commitment, tenderness and hope. The poetic persona reclaims the sun owed to her, as in the poem "Séance" where the participant no longer summons the dead person's spirit -

Loved ones if you are listening, I need no proof of you. Instead give me a sign that I am here (64)

The dead now "shiver light back / down into our bare bones" ("In The Butterfly House", 68) and life flows again in the abundant rivers that irrigate this section with suitably swift poetic rhythms. As in "Swim Lesson, Goa", trust substitutes for fear and the body will not be erased - "such is the compulsion of it to be acknowledged" (Ní Churreáin, qtd. in Frank). Instead the body takes delight in its five senses while the poet patiently kneads the dough of verse.

Bloodroot is Annemarie Ní Churreáin's debut collection but this should not mislead readers into thinking it is a fortuitous achievement. Her control over rhythm, imagery and lineation attests to a command of form and thorough training. Some of the poems here included first saw the light in The London Magazine, Poetry Ireland Review, The SHOp, Agenda Poetry Journal and The Stinging Fly, while Ní Churreáin herself has been awarded literary fellowships in Germany, the United States and the United Kingdom, and has been the recipient of a Next Generation Artists Award from the Arts Council of Ireland. This trajectory and its outcome in Bloodroot attest to the making of a good poet who, we expect, will continue to provoke and move us with her art.

\section{Note}

"it was among the brambles / you hid your tongues crossed hands behind your backs / perhaps because we would not deny / the witches' legacy”. [My translation from Galician].

\section{Works Cited}

Aleixandre, Marilar. Abecedario das arbores. Santiago de Compostela: Editorial Compostela / Concello de Santiago de Compostela, 2006.

Frank, Lisa. "The Shaping of a Cross-Border Book Tour". The Irish Times. 14 November 2017. https://www.irishtimes.com/culture/books/the-shaping-of-a-cross-border-booktour-1.3290265.

Ní Churreáin, Annemarie. "I Was Raised in the Shadow of Men who Wanted to Conquer Wildness". The Irish Times. 26 October 2017. https://www.irishtimes.com/culture/books/i-was-raised-in-the-shadow-of-men-whowanted-to-conquer-wildness-1.3268313. 
Manuela Palacios González is Senior Lecturer of English at the University of Santiago de Compostela in Spain. She has directed four research projects on contemporary Irish and Galician literature that have been funded by the Spanish government and has edited and coedited eight books in relation to this topic.

manuela.palacios@usc.es

Conversations with Friends.

Sally Rooney.

London: Faber and Faber, 2017. 321 pp.

ISBN: 978-0-571-33313-4

Reviewer: José Francisco Fernández (University of Almería, Spain)

One of the most striking effects of reading Sally Rooney's splendid first novel is that the reader does not really know what makes it so compelling, in that it is the kind of narrative that reads fluently and without obstacles. One has the feeling of gliding through an apparently comfortable terrain, only to discover later on just how bumpy the journey has been, and that the author has taken you effortlessly through a variety of different altitudes. In fact it is only on a second reading, and through a reflection on the novel's internal structure, that one can fully appreciate just how intelligently the work has been crafted. The author possesses a high degree of narrative cunning, which is particularly directed to negotiating her own complex relationship with the protagonist of the novel, and this is perhaps what makes the narrative so intriguing.

The story is based around the coming of age of Frances, a 21-year-old Irish student at TCD. Her entrance into the adult world anticipates the usual negotiations with the complexities of grown-ups, although in her case the situation is complicated in a number of ways. Frances, who has had a sentimental relationship of sorts with her best female friend, Bobbi, is not someone who is easily impressed. Together they meet an older and wealthy couple: Melissa is a photographer, and her husband Nick, an actor. Most of the book recounts the liaisons of Frances and Nick, their ups and downs, their delusions and joys. The chronicle of the affair is sprinkled with witty dialogues, Frances normally gaining the upper hand; for example, when Nick reflects that he seems to be drawn to women writers, Frances retorts: "You just like women who can wreck you intellectually" (245). This is one of the great assets of the book, the animated exchange of opinions among the protagonists, almost all of them belonging to the same progressive, well-educated and leisured social stratum: "We often had political discussions," reflects Frances at some point, "in which we all shared similar positions but expressed ourselves differently" (241). Frances's sharp intelligence shines through in these conversations, although, as a counterpart to this she is not able to engage empathically with others: one of her personality traits consists of eschewing any display of emotion so that she remains constantly distant. Wickedly, the author puts her into situations in which her coolness simply cannot hold. The irony which Rooney projects pours down upon her main character, and the way that Frances deceives herself over her emotional detachment, is one of the principal achievements of the narrative. Issues related to the body and its 
ailments also play an important role in the protagonist's tug-of-war with her own perceptions of reality, in that Frances suffers from endometriosis, a condition that she keeps to herself most of the time, but which makes her confront facts such as the painful physicality of existence and the body as the site of illness and discomfort.

The uninhibited description of female sexuality is another element worthy of note and in this sense Rooney joins the ranks of other female Irish writers who handle physical interaction with sexual partners in a direct way, often speaking in the first person, as is the case in this novel. Inevitably we must mention Eimear McBride here, as the main exponent of this current in contemporary Irish writing. Curiously enough, McBride's book, The Lesser Bohemians (2016) (reviewed in issue 13 of Estudios Irlandeses) has many interesting connections with Rooney's first incursion into long-form narrative: in both cases it is a young woman who falls in love with an older man, a handsome actor, someone who by definition is used to being in the limelight and who is often admired. In both stories he is the object of female desire, with the authors thus reversing the traditional representation of gender roles. It should also be said, though, that the protagonist's self-exposure in McBride's novel is more radical and visceral than in Rooney's Conversations with Friends. In a way, Rooney's style, discursive, detached, effortlessly elegant, is connected to a previous tradition in novel writing; it is no coincidence that Frances is reading Middlemarch for her course in English literature, and this creates suggestive intertextual connections in the narrative. McBride, meanwhile, has created her own school and her style is more experimental, even in terms of typography; the fact that Arnold Schoenberg's Verklärte Nacht, an innovative and disturbing musical piece for string orchestra, is the artistic work which presides over The Lesser Bohemians indicates the author's artistic referents.

Conversations with Friends is a very Irish novel, both in terms of urban geography and in the different mindset which is required in the capital, Dublin, and in a small town setting. It is a very contemporary Irish novel, though, in that gay couples no longer cause a stir, the church is hardly mentioned and classic fictional figures like the alcoholic father, as novelist Claire Kilroy has noticed, are relegated to a residual role. Reviewing the book, Kilroy wrote "Rooney sets her story in the post-crash era, among a Dublin elite. Her characters work in the arts and denounce the evils of capitalism while living off inherited wealth. The novel, indeed, is almost post-Irish" (Kilroy).

Finally, Conversations with Friends is remarkable as cultural history. It faithfully portrays the life of the millennials in the first decades of the 21 st century, in a way that is reminiscent of the early Generation X narratives of the final years of the previous century the kind of fiction that first dealt with the issue of highly qualified young people having no future prospects. Frances and Bobbi, through their contact with Melissa and Nick, enter into a world of affluence, but coming from a rich family Bobbi is more at ease in these genteel surroundings, but for Frances, who hails from the drab provincial lower-middle classes, the contrast is more pronounced, as also is her perception of wealth and privilege. A very revealing example of Rooney's sharp dissection of modern society is the way she deals with the topic of money and the value it represents for those who do not have instant access to it. Money is something that her acquaintances do not seem to care about, whereas for Frances it is a matter of real anxiety. At one point in the novel Frances comes close to experiencing real poverty, when her unreliable father stops paying her allowance and she has to survive a month on the little cash she has herself, plus food she borrows from Bobbi. It is, admittedly, a particular kind of poverty, the kind suffered by a privileged citizen of the West, a student who has obtained financial assistance to pay her university fees and who exists within the protective embrace of the National Health Service. But this does not diminish the notion that Frances is indeed the representative of a generation that has somehow been stranded by its elders. Conversations with Friends is not the militant novel of an activist, nor does it propose 
a radical agenda for social change, but the description of a disoriented youth is portrayed with precision and it raises relevant questions about the future. As Torsten Bell, director of the Resolution Foundation, puts it, "When an entire cohort is not succeeding, everyone understandably feels a real need to fight tooth and nail to keep what they've got. The rich are much better suited to win that war. That's a real challenge for social mobility, and a disaster for politics" (Roberts 37).

\section{Works Cited}

Kilroy, Claire. "Conversations with Friends by Sally Rooney Review - Young, Gifted and Self-Destructive". The Guardian. 1 June 2017. 12 December 2017. https://www.theguardian.com/books/2017/jun/01/conversations-with-friends-by-sallyrooney-review

Roberts, Yvonne. "Millennials Are Suffering... Is it Really the Baby Boomers' Fault?". The Observer. 29 April 2018. 36-38.

José Francisco Fernández is Senior Lecturer in English literature at the University of Almería, Spain. His most recent work focuses on the narrative of Samuel Beckett and his reception in Spain, including articles on Beckett published in specialized journals such as Journal of the Short Story in English, Journal of Beckett Studies, AUMLA, Studi Irlandesi and Arcadia, among others. He has also translated into Spanish three novels and three short stories by Samuel Beckett. His translation of Texts for Nothing was awarded with the AEDEAN translation prize in 2016. He teaches Anglo-Irish literature in the Master's Degree in English Studies at the National Distance Education University (UNED) and is general editor of the journal Estudios Irlandeses.

jffernan@ual.es

Last Stories.

William Trevor.

London: Viking/Penguin 2018. 213 pps.

ISBN 978-0-241-3376-9

Reviewer: Hedwig Schwall (Leuven Centre for Irish Studies, Belgium)

In his Last Stories which were published almost two years after his death, Trevor shows he kept up his master's craft till his last volume. The overall theme is, as usual in Trevor, a strong rootedness in the past and the characters' prevarication in wanting and not wanting to know. The result is inertia resulting in a status quo or a lack of empathy leading to tragedy; sometimes the inertia compounds the lack of empathy. Only two stories stand out as being different, the second and the second to last: in the former, the female protagonist seems to have taken physical action (killing "The Crippled Man" of the title), in the latter she gives the decisive psychological push to resolve the situation.

The opening story, "The Piano Teacher's Pupil", is a typical example of Trevor's reticent protagonists. The pupil is a very gifted player but he is also a kleptomaniac. Though 
the boy steals something on each occasion, Miss Nightingale does not comment on it but it makes her wonder whether maybe she has misinterpreted everybody in her life: "If a lonely father had been a calculating man it mattered less now... She had been the victim, too, of the boy who had shown off to her ... She had been the victim of herself, of her careless credulity, her wanting to believe what seemed to be" (9). In the third story it is Anita's inertia and lack of empathy which causes the sad end: her anger with her friend Claire, who became one of Anita's husband's lovers, does not allow her to accept Claire's offer of friendship after Gervaise's death. In the next story again a lack of empathy is compounded by inertia. On the one hand there is Mr Ravenswood, a customer in the bank where Rosanne works, who invites her to dinner. Later he confesses to her that his wife died because of his reckless driving, but Rosanne is so overwhelmed by the riches in his house that she does not pay attention to the man's needs for unburdening his conscience. On the other hand, Rosanne's partner Keith pushes her to get money off him, and she cannot extract herself from him. "Mrs Crasthorpe" is Trevor's version of Joyce's "A Painful Case", as Etheridge does not give Mrs Crasthorpe much attention, though he is somewhat intrigued by her. Yet Trevor's character has her own drama, as she is split between her desire for a cultivated life and her penchant to love a "persistent offender". The sixth story, "The Unknown Girl" I find the most subtle. Here, Trevor whirls oppositions and parallels into a tight little drama, in which the three main actors represent degrees of empathy. Mrs Harriet Balfour, widowed but consoled by the company of her son and the objects in the beautiful house which keep the happy memories of her husband alive, is a smooth, cautious and socially committed being. She is informed by a soul-searching cleric that "the unkown girl", her former cleaner, died in what seemed a case of suicide. In the following months the discrepancy between the humble cleric who is tormented about not having been able to help the girl and Harriet's son, Stephen, who turns out to be a 'clinical' paediatrician who refused help, brings the revelation that the cocoon she offered her son was maybe not the right way of life. The next story, "Making Conversation", stands out a bit oddly, hinging on a protagonist whose actions are dictated by a strange combination of pity and revenge. In her youth, Olivia had felt slighted by a man who, pitying her, had "made conversation" with her. Now Mrs Vinnicombe comes to claim her husband back from Olivia, but she merely makes conversation with the woman. Like Claire in "The Caffè Daria", Mrs Vinnicombe is much more generous in her emotions than the protagonist.

The remaining three stories are all built on a chiasmus. The painter of "Giotto's angels" meets a "woman with a brooch" who gives the protagonist work and a workplace while Denise, a poor prostitute, steals all his money from him, but then thinks of going back and starting a life of companionship with him. Likewise, "An Idyll in Winter" shows a chiastic development of the main characters. First Anthony, Mary Bella's private tutor, teaches her to use her imagination. Later, when he leaves his family to come and live with her, it is Mary Bella's imaginative sympathy with the deserted family which will reverse the situation. The final story, "The Women", doubles the sets of complementary characters: on the one hand there are Miss Cotell and Miss Keble; the first has known love but has given her child in adoption, the second hasn't had a deep relationship but "knew that it was she, in the end, who ordered their lives and wielded power" (198). On the other hand, there is the rich $\mathrm{Mr}$ Normanton and his daughter Cecilia who starts surmising that she is adopted; but the more he opens up, the more she retreats into her inner self, so that the situation finally remains undisclosed.

The writing is vintage Trevor, as I will briefly illustrate in this volume's themes and style. The overarching theme is the family; but, like in Trevor's other collections, religion is mentioned too. Usually Trevor's stories either criticize the institution ("Of the Cloth" in The Hill Bachelors (2000), "Justina's Priest" in A Bit on the Side (2004), "Men of Ireland" in Cheating at Canasta (2007)) or they focus on a more mystic personal attitude (as in "The 
Virgin's Gift" (The Hill Bachelors) or "The Dressmaker's Child" (Cheating at Canasta). In Last Stories, "Giotto's Gift" combines the two strands, as the amnesiac painter of saintly topics is considered a potential paedophile, while he is not in the least interested in sex or money, only in his painting of angels.

Like in previous volumes the stories are linked by motifs, techniques and style. A recurring motif in Trevor is how people are determined by their past. Miss Nightingale sees her life as a series of relations of which she was the victim; Anita's sense of being wronged in the past stands in the way of forgiveness and friendship; Stephen's ingrained caution does not allow him to face the plea of "The Unknown Girl", Miss Keble's lifelong pent-up jealousy may destroy her friend's chances to meet her lost daughter. Yet the past is not always unfortunate: Mary Bella "knew ... that the past would always be there, around her" (161), but it is positive, an openness reflected in "The big, wide door was as it always had been" (162).

These themes are supported by Trevor's short story techniques: the way he uses spatial relations, objects, clothes and body language to characterize an atmosphere. Often Trevor uses irony here: the history of "The Caffè Daria" contrasts with the way in which Anita, one of its oldest habitués, behaves; in "The Unkown Girl" Harriet's "airy", everchanging garden contrasts with her son's room "never changed", thus reflecting how he is "empty of emotion" (110). Often Trevor's characters are so tongue-tied that they have to revert to "thing language", like Claire in "The Caffè Daria": unable to express her sadness about losing both her partner and her friend, she disappears: "There is no note: the open door said all there was to say" (52).

On the level of style I want to highlight four features Trevor frequently used throughout his work, and does again in Last Stories: the negative phrases, the (ironic) characterization through names, cognitive verbs and the passive voice. "An Idyll in Winter" starts with "Mary Bella didn't remember when she woke up and then she did: he hadn't come" (155). As Hermione Lee pointed out about Cheating at Canasta "Typically, it's a negative phrase, this book is full of things that don't work [and] can't be said" (6). In "Making Conversation" it is the names which underline the basic opposition between $\mathrm{Mr}$ and Mrs Vinnicombe on the one hand and Olivia on the other. Not only does the married couple get an outstanding family name, they do not get a first name, which stresses the impact of their marital relation. Olivia, on the other hand, gets no surname, and as she sees things merely from her own viewpoint: her partner is but "The man Olivia lives with" (113). Houses too get names: ironically, the home where Miss Keble and Miss Cotell so carefully draw the curtains (on respectively their jealousy and frustrated mother love) "was called Sans Souci" (204). Finally, the cognitive verbs which express doubt (the house painters "guessed and wondered, supposed, surmised" (33) what had happened to the Crippled Man; "Etheridge guessed his way through the mystery of Mrs Crasthorpe" (91)) connect with Trevor's marked predilection for the passive voice, which entirely fits the author's exploration of uncertainty. At the start of "The Crippled Man" Rosanne puts on a brave face in her sad situation on the lonely farm, but after the disappearance of the crippled man she tries to efface herself: "The tray was left on the step of the door" (26). Likewise, the women who try to win over Cecilia are very diffident: "Violets were held out to her to smell" (195). It is this "in-between" within a personality which Trevor seems to deem a core thing. Maybe we could sum up Trevor's image of the human being as 'a certain prevarication which is a constant element in the changing events of one's life'? This would tie in with his characteristic combination of cognitive verbs of doubt with his frequent use of the adverb "always". So Mrs Crasthorpe "... always had. She always would" (88) love the low life; Mary Bella feels she belongs to the farm: "The sun had reached the kitchen... it always does" (180). Rosanne too, knows she is stuck in the "hinterland that was hers and had been all her life" (56) and in her habits: "Her thoughts were full of Keith, as she had known they would be" (56). 
There is no doubt that in Last Stories Trevor still proves himself an expert in the charting of micro-shifts in the minds and emotions of (mostly) middle-aged middle-class people. To alleviate the darkness of his protagonists' struggles I would have hoped the author would have inserted some humour in his stories, but in his consistency and subtlety Trevor is definitely one of the masters of the Irish short story.

\section{Works Cited}

Lee, Hermione. "Ghosts of Ireland past ... and present". The Guardian, Saturday Review. 4 August 2007.

https://www.theguardian.com/books/2007/aug/04/featuresreviews.guardianreview4

Trevor, William. The Hill Bachelors. London, Penguin, 2000.

. A Bit on the Side. London: Penguin, 2004.

. Cheating at Canasta. London: Penguin, 2007.

Hedwig Schwall is director of the Leuven Centre for Irish Studies (LCIS). She is co-editor of the series Irish Studies in Europe (ISE) and editor of Volume 8 (Boundaries, Passages, Transitions), literature editor of RISE, the Review of Irish Studies in Europe, where she was special editor of issue 2.1 on Irish Textiles: T/issues in Communities and their Representation in Art and Literature). She is now preparing a book on Parent-Child Relations in Contemporary Irish Fiction. She published the website Kaleidoscope: writers@work, where 50 Irish fiction writers describe what writing fiction means to them; this will be published as a book, The Danger and the Glory (Arlen House, February 2019).

hedwig.schwall@kuleuven.be

Rhythms of Writing: An Anthropology of Irish Literature.

Helena Wulff.

Bloomsbury: London, 2017. 162pp.

ISBN 978-1-4742-4413-8

Reviewer: Christina Hunt Mahony (Trinity College, Dublin)

Irish writers and their bodies of work are the subject of scrutiny by journalists, literary critics, linguists, academicians, historians, biographers, film-makers and others. They have been analysed by period, genre, gender, thematically, stylistically, and even psychologically. These writers have, in turn, approached Irish society forensically for generations, often treating their subject matter - the Irish people - as anthropological subjects. Helena Wulff's book is, to my knowledge, the first time that an anthropological lens has been focused on Irish writers themselves and what constitutes their communities both public and private. They are, it seems, a fascinating group to study in their natural habitats.

Wulff, Professor of Social Anthropology at Stockholm University, benefits from being in the best of all anthropological positions, as both an insider and an outsider. She has spent much time in the country, and has befriended, and ingratiated herself with, a variety of contemporary Irish authors. She is most interested in understanding the productive environment in which an Irish writer is bred and develops to maturity. In these pages she examines not only the home-based writer and his or her place in the society, but also the 
nurturing and flourishing of Irish literary reputations abroad. She is most interested in prose writers - few poets' and dramatists' careers are mentioned here - but the book's thesis and supporting evidence seem sound enough to be applied to writers in those fields.

Although many writers and other creatives in Ireland may complain bitterly that there is insufficient support for their cohort in today's Ireland (The biggest problem for writers now is probably one which affects the society at large - skyrocketing house prices and rents and an egregious housing shortage). Wulff illustrates effectively, however, that even from the primary school level, government initiatives such as the Writers in Schools scheme, and other private efforts such as Roddy Doyle's laudatory Fighting Words programme provide encouragement and early aperçus for budding talent. Wulff continues through the life cycle, cataloguing creative writing degree programmes and other adult courses throughout the 32 counties, and other supports to the process, including writing bursaries and subventions to literary magazines. Literary and arts festivals, and that utterly unique Irish institution, The Summer School, combine to provide initial small scale publishing opportunities, and intimate venues where seasoned and new authors alike can read from their works. Another Irish institution - the book launch - is a constant on the Irish horizon (whereas in the UK it is the preserve of a privileged few writers). In Ireland, in season, there can be an embarrassment of choice for launch goers in Dublin and other cities, and in many smaller towns. And we haven't even begun to consider, The Writers' Centre, Poetry Ireland, Aosdána, PEN, and the various media outlets that can and do highlight literary talent, offer paid work, exposure and more subventions. Television and radio arts programme give time and space to new and established writers, and individual slots on mainstream entertainment programmes are available, such as that of Ryan Tubridy's daily morning radio show. Another radio host, Sean O'Rourke, is one of many who feature a broadcast book club and there are podcasts galore. Lyric radio, the classical music station, hosts an arts programme that includes literature and drama and interviews artists and reviews their work. Arena, with Sean Rocks, and various multi-media arts programmes hosted by John Kelly have all given prominence to writers, along with Olivia O'Leary's new Poetry Programme on Radio One. Broadcast and print media interviews are also legion, offering the new writer with a book appearing to have a biographical profile in print to coincide with the publication of a new volume.

It might be argued that these opportunities are to be found in other countries, and, indeed, they are - but perhaps not in such profusion. Then there are the prizes. Irish writers do love their prizes, and are eligible for more than writers in most countries because of their scope across the Anglophone world. If one adds in the book tours, the tireless work of agents (sometimes in several countries), the marketing efforts of publishers and the opportunities provided for writers to review each others' works in newspapers and journals and even to write op-ed pieces in the media, one can begin to piece together what makes up the environment of this rarefied species. One might also begin to wonder - is it endangered? If so, what are its predators? Is it protected? Should it be?

Wulff's interlocutors are numerous, and with only a couple of exceptions, they are named. Prominent among them are Éilís ní Dhuibhne, Colm Tóibín, Colm McCann, Anne Enright, Deirdre Madden, the aforementioned Roddy Doyle, John Banville, Celia de Fréine and Belinda McKeon. That list alone indicates Wulff's democratic range with a balance of gender and reputation - some preeminent household names, others less known but with wide readership.

An anthropologist relies on taxonomy. There are five major categories of Irish writer in terms of reputation, Wulff asserts. These categories reflect not only talent and accomplishment, but also degrees of reputation, fame and prominence. There are those who publish in Irish and in English and have reputations mostly in Ireland; those who publish in English only and have reputations mostly in Ireland; those with an international reputation 
who publish abroad but live in Ireland; those who have moved to the US (not elsewhere for Wulff) and have an international reputation; and Northern Irish writers who publish exclusively in Britain. The investigative research then proceeds to delineate the benefits that accrue to each type of writer, and the reputational rewards he or she might expect under the circumstances.

The author points out a feature in the developmental stages of Irish writers' lives which might not be immediately apparent, to wit, the large number who either earned their living as journalists before embarking on creative writing, and the equally large number sustained by ongoing and multiple journalistic opportunities. Wulff also points to the existence of government subsidized literary journals which provide a nursery for talent, suited as they are to that pre-eminent of Irish prose forms, the short story; but also to excerpting longer works of fiction in progress. Her extensive interviews with critical players in what might be called the creative support industry are revealing, especially with Declan Meade, founder and editor of The Stinging Fly, a literary magazine and book publisher; and Anthony Farrell of Lilliput Press, a niche publisher avant le mot.

As valuable as this book is, it does have limitations. It may well be in the nature of such undertakings that they can be seen as nearly inevitably rendering themselves out-dated, but The Rhythms of Writing is a bit confusing in this regard. A recent enough talent, Donal Ryan, is discussed in some detail, but there seems no awareness of a veritable slew of new writers coming up alongside and immediately behind him. These are writers who had begun winning prizes years ago, such as Eimear McBride, Lisa McInerny, and Kevin Barry (who has also done much to foster the writing of others by guest editing literary journals, and embarking on Winter Papers, an impressive annual arts anthology). And, along with these and many others publishing in the last decade (Rob Doyle, Paul Lynch, Colin Barrett, Sara Baume, Claire-Louise Bennett and many more)) there have been seismic paradigmatic thematic shifts which make Wulff's categories for Irish prose themes seem nearly quaint. It suggests perhaps that the book took a long time from its completion to publication, but then there are other recent reference points, like Brexit, appearing within her pages.

Although Wulff notes how important "product placement" (to be crude about it) of a short story or poem in The New Yorker or Granta can be for an Irish writer's book sales, there is no mention of Paul Muldoon, who served as poetry editor for The New Yorker for a decade. Muldoon embodies the kind of expatriate writer she discusses in one of her five categories, to say nothing of having been well-placed to promote the work of other Irish writers. He is also one of the many Irish writers who hold currently, or have held in the recent past, lucrative and prominent sinecures at American universities. Wulff does write about Seamus Heaney and Colm Tóibín in this regard, but it is an arena that called for more in-depth focus if only because of the degree of prominence in American letters these writers since Ben Kiely and Frank O'Connor have enjoyed, and which resulted in heightened reputation both inside and outside Ireland, while providing crucial financial security. Paul Muldoon's directing the Creative Writing programme in Princeton, and Poet Eavan Boland filling the same job at Stanford for much longer, have not only raised the profile of Irish writing but influenced new generations of young writers abroad.

A couple of remaining quibbles. Wulff is forced in places by the book's weak construction to refer us rather too often back and forth either to things she's already written or what is to follow. She chooses to highlight the maternal in literary autobiography, and while mothers can and do figure, the form is famous (or infamous) for its Oedipal tugs of war between writers and their fathers. Finally, the prominent London-based literary agent Paul Feldstein, who represents so many Irish writers, is referred to as Feinstein as least twice before his name is recorded correctly - in the same paragraph as one of the erroneous references. 
Rhythms of Writing is an eye-opening and intelligent book that de-familiarizes a world one might have thought one knew. It may and should become the prototype for more such valuable work to follow.

Christina Hunt Mahony directed the postgraduate Center for Irish Studies at The Catholic University of America in Washington, D.C. She is the author of Contemporary Irish Literature: Transforming Tradition and editor of Out of History: Essays on the Writings of Sebastian Barry. She has recently contributed chapters to The Oxford Handbook of Modern Irish Theatre and The Cambridge History of Irish Autobiography and is a Senior Research Fellow in The School of English at Trinity College, Dublin.

cmahony@tcd.ie 